\title{
Children's Perspectives on the Medical and Cultural Aspects of Circumcision
}

\author{
Selda Rizalar, ${ }^{1, *}$ Esra Tural Buyuk, ${ }^{2}$ and Nejla Yildirim ${ }^{3}$ \\ ${ }^{1}$ Istanbul Medipol University, Istanbul, Turkey \\ ${ }^{2}$ Ondokuz Mayis University, Samsun, Turkey \\ ${ }^{3}$ Ondokuz Mayis University, Health Application and Research Center, Samsun, Turkey \\ "Corresponding author: Selda Rizalar, Istanbul Medipol University, School of Health Science, Department of Nursing, Ataturk Bulvari No 27 Unkapanı Fatih, Istanbul 34083, \\ Turkey. Tel: +90-2124534800, Fax: +90-2125317555, E-mail: srizalar@medipol.edu.tr
}

Received 2016 June 15; Revised 2016 August 08; Accepted 2016 September 12.

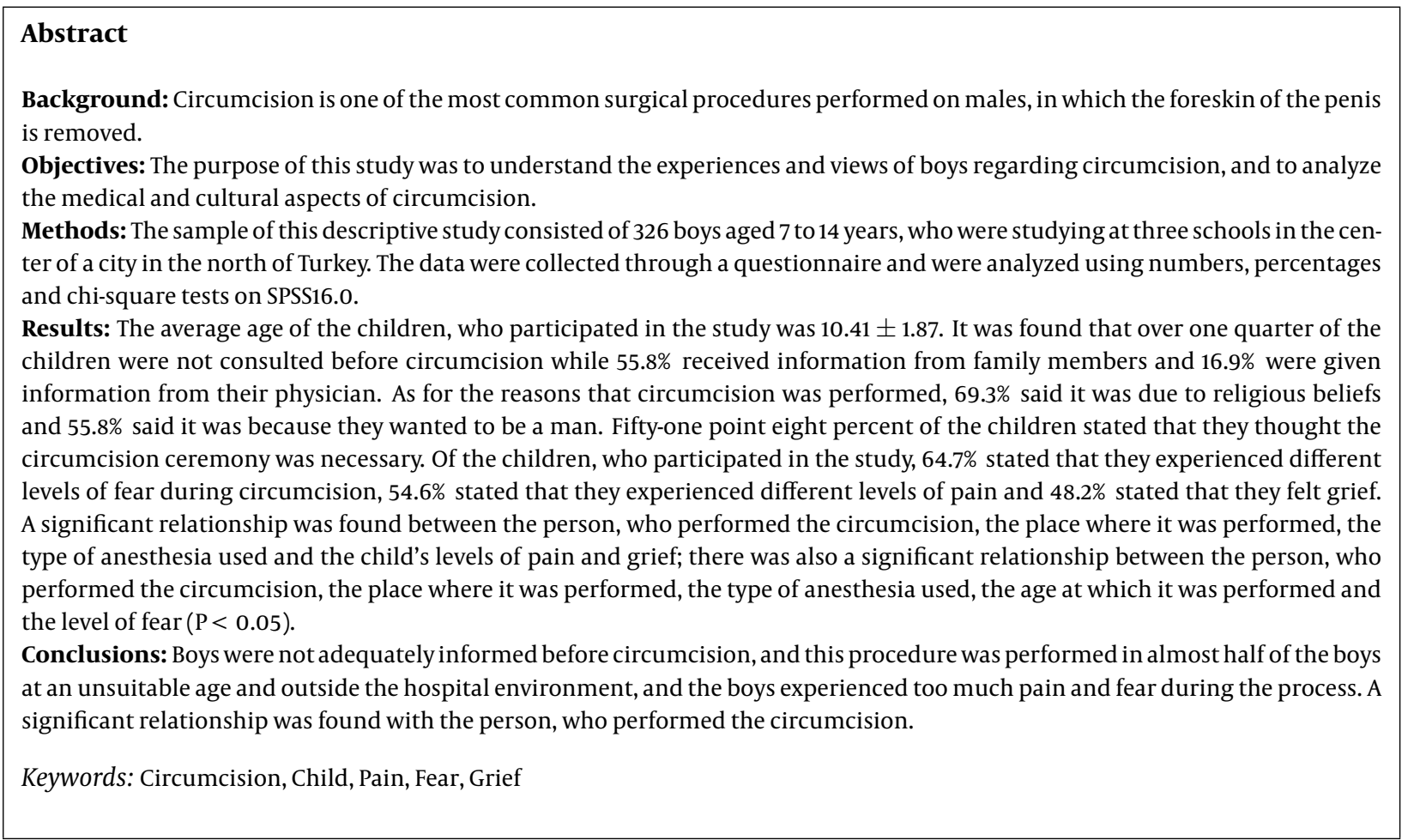

\section{Background}

With no doubt, circumcision is the oldest and most performed surgical operation throughout the world (1). The world health organization (WHO) estimates that overall 30-33\% of the males at or over the age of 15 are circumcised (2). In Turkey, most of the population is Muslim, and almost all males are circumcised; however, in contrast to Western societies, circumcision is performed at older ages in the Turkish population (3).

Circumcision is also considered to be a symbol of a boy entering into manhood and his ability to reproduce. In addition to its association with religious beliefs and traditions, circumcision is directly associated with health. Debates and studies on the benefits, indications, suitable age, techniques and complications of circumcision are ongo- ing. There are many factors that result in these discussions. Religious beliefs, traditions, human rights, financial issues and scientific data on circumcision comprise important aspects of these debates.

The ethical aspect of circumcision is not also clear. Some sources claim that child circumcision is interference and that it is against human rights and is unethical $(4,5)$. However, some important studies have identified the serious benefits of circumcision and have demonstrated that some illnesses can be prevented with circumcision (1, 68). Circumcision performed during the phallic phase may cause acute psychological problems in children, and thus, it is recommended to perform it before three years or after six years of age $(9,10)$. It should be performed in hospitals by surgeons, who are familiar with the procedure (11). Circumcisions that are performed outside the hospital can 
cause more complications (12). Therefore it is important to inform people that circumcision is a standard process with few complications. There are some studies that report on the parents' views towards circumcision $(13,14)$. However, there are a limited number of studies on children's ideas about this procedure. Thus, we believe that experiences, emotions and recommendations of school children will contribute to the literature on circumcision.

\section{Methods}

The study had a descriptive and cross-sectional design. The purpose of this study was to identify the experiences and views of boys between 7 and 14 years of age on circumcision and to analyze the procedure's medical and cultural aspects as seen by children. The study sample consisted of all boys, who were circumcised between the ages of 7 and 14 years, who were studying at three schools, one private school and two state schools, in central city. All students that could be contacted were included in the sample. There were 1324 students at the two public schools and 450 students at the private school that were selected in the specified city. Samsun is a big city in the coast of the black sea region in Turkey. The total number of male students was 700 from the public schools and 162 from the private school. Thus, the study sample included 862 students. Uncircumcised boys were excluded from the study. From the study sample, 269 students from the public schools and 57 students from the private school were included in this study. A participation rate of $35.18 \%$ was achieved for the public schools, and a participation rate of $38.42 \%$ was achieved for the private school. Data were collected during March 2014.

Written permission was obtained from the competent institutions before the study was conducted (42276601/604.01/300736). During the parent-teacher meeting, the study procedures were explained and the questionnaire was introduced to the boys' parents. The parents, who permitted their children to take part in the study, were noted on class lists with the names of the parents and students. After the children, who were permitted to take part in the study gave their oral consent, the questionnaires were administered in the classes. The questionnaire consisted of 24 questions that analyzed views and experiences of the children, who were circumcised. There were two questions regarding sociodemographic features and 22 questions regarding the children's views on circumcision. The data were collected by a questionnaire that was prepared by the researcher after reviewing the literature.

The children whose parents gave consent for their participation in the study were identified, and the questionnaire was administered to these children in class, after their oral consent was provided and their teachers were informed.

\subsection{Data Analysis}

The data obtained from the study were evaluated using SPSS for Windows 16.0 software (IBM SPSS Statistics, Chicago, IL, USA). In the analysis of the data of the participants, numbers, percentages and chi-square tests were used. A P value of less than 0.05 was considered statistically significant.

\section{Results}

The average age of the children, who participated in the study was $10.41 \pm 1.87$, and $82.5 \%$ were studying at a public school. Over one-quarter of the children were not informed about circumcision, while $55.8 \%$ received information from family members and $16.9 \%$ received information from their physician. Seventy-six point four percent of the children stated that they underwent their circumcision willingly. Forty-four point eight percent of the children were found to have been circumcised between the ages of three and six years. When the students were asked which age was the most suitable for circumcision, $42.3 \%$ said it was during infancy, and when they were asked for their reasons, they said that it was the most suitable time (23.3\%), it would not result in pain (17.8\%), it was easier (16\%) or that it avoided fear (11\%). Fifty-four percent of the boys stated that they were circumcised by having the circumcision area anesthetized, while 33.1\% stated that they were circumcised under general anesthesia. A health officer performed the circumcision for $51.5 \%$ of the boys, and the remaining $48.5 \%$ of the boys had their circumcision performed by a physician. In the study, $47.2 \%$ of the children had been circumcised at a hospital, and $42 \%$ had been circumcised at home (Table 1).

As for the reasons that circumcision was performed, 69.3\% said it was due to religious beliefs, and $55.8 \%$ said it was because they wanted to be a man. Fifty-one point eight percent of the children stated that they thought the circumcision ceremony was necessary, while $68.4 \%$ stated that they had already had their circumcision ceremony(Table 2). Of the children, who participated in the study, $64.7 \%$ stated that they experienced different levels of fear during circumcision, $54.6 \%$ stated that they experienced different levels of pain and $48.2 \%$ stated that they felt grief.

When the association between the children's state of experiencing fear and independent variables was examined, a significant difference was found between the place where the circumcision was performed, the person who performed the circumcision, the type of anesthesia used, 
Table 1. Characteristics of the Children Regarding Their Circumcision $(n=326)$

\begin{tabular}{|c|c|}
\hline Characteristics & No.(\%) \\
\hline \multicolumn{2}{|l|}{ School type } \\
\hline Public school & $269(82.5)$ \\
\hline Private school & $57(17.5)$ \\
\hline \multicolumn{2}{|l|}{ Being informed about circumcision } \\
\hline Yes & $229(70.2)$ \\
\hline No & $97(29.8)$ \\
\hline \multicolumn{2}{|l|}{ The person who gave information on circumcision } \\
\hline Parents together & $113(34.7)$ \\
\hline Not informed & $89(27.3)$ \\
\hline Doctor & $55(16.9)$ \\
\hline Father & $50(15.3)$ \\
\hline Mother & $19(5.8)$ \\
\hline \multicolumn{2}{|l|}{ The child's attitude towards circumcision } \\
\hline Willing & $249(76.4)$ \\
\hline Unwilling & $77(23.6)$ \\
\hline \multicolumn{2}{|l|}{ Age of circumcision } \\
\hline $1-2$ years of age & $53(16.2)$ \\
\hline $3-6$ years of age & $146(44.8)$ \\
\hline 7 years and older & $127(39,0)$ \\
\hline \multicolumn{2}{|l|}{ Ideal age to have circumcision according to the child } \\
\hline At age I has been circumcised & $174(53.4)$ \\
\hline Newborn & $138(42.3)$ \\
\hline Older age & $14(4.3)$ \\
\hline \multicolumn{2}{|l|}{ The reason for picking the ideal age for circumcision } \\
\hline Because it is the most suitable time & $76(23.3)$ \\
\hline Not to feel the pain & $58(17.8)$ \\
\hline Because it is easier & $52(16.0)$ \\
\hline Not to remember & $43(13.2)$ \\
\hline To be informed & $44(13.5)$ \\
\hline Not to be scared & $36(11.0)$ \\
\hline No answer & $17(5.29$ \\
\hline \multicolumn{2}{|l|}{ How was the circumcision performed } \\
\hline With anesthesia & $108(33,1)$ \\
\hline Circumcision area anesthetized & $176(54.0)$ \\
\hline No anesthesia & $42(12.9)$ \\
\hline \multicolumn{2}{|l|}{ How the child prefers circumcision } \\
\hline It should be made under anesthesia & $145(44.5)$ \\
\hline It should be made by anesthetizing the circumcision area & $152(46.6)$ \\
\hline It should be made without anesthesia & $29(8.9)$ \\
\hline \multicolumn{2}{|l|}{ The person who performed circumcision } \\
\hline Surgeon & $158(48.5)$ \\
\hline Circumciser & $168(51.5)$ \\
\hline \multicolumn{2}{|l|}{ The place where circumcision was performed } \\
\hline At home & $137(42.0)$ \\
\hline In hospital & $154(47.2)$ \\
\hline Mass circumcision & $35(10.7)$ \\
\hline Total & $326(100.0)$ \\
\hline
\end{tabular}

the age at which circumcision was performed and the state of experiencing fear $(\mathrm{P}<0.05)$. The children, who were circumcised at home, those who were circumcised by people other than physicians, those who were anesthetized locally and those who were between the ages of three and five years were found to have more fear compared with the other children (Table 3 ).

When the associations between the independent variables and the pain felt by children during circumcision were analyzed, a significant association was found between the place where the circumcision was performed, the person, who performed the circumcision and the type of anesthesia used $(\mathrm{P}<0.05)$. The children, who were circumcised at home, those who were circumcised by a health officer and those who were anesthetized locally were found to have felt more pain compared with the other children (Table 3). When the association between the independent variables and the state of grief during circumcision were analyzed, a statistically significant association was found between the place, where the circumcision was performed, the person who performed the circumcision and the type of anesthesia used $(\mathrm{P}<0.05)$. The children who were circumcised at home, those who were circumcised by a health officer and those who were anesthetized locally were found to have felt more grief compared with the other children (Table 3 ).

\section{Discussion}

Children's experiences during circumcision and their suggestions are also important; however, a limited number of studies exist on this subject. It has been stated in the literature that circumcision should not be performed during the phallic phase because it may cause augmentation and persistence in castration anxiety. In our study, $44.8 \%$ of the boys were circumcised during the phallic phase. In a previous study that was conducted to understand the behaviors and knowledge of mothers on circumcision, Yilmaz et al. found that most of the mothers preferred the phallic phase for circumcision because of their low levels of education (15). In their study, Ustuner et al. also found that $42.2 \%$ of the parents preferred the same age period for circumcision (16). There is also information in the literature that circumcision is performed between 3 and 13 years of age, before puberty in Turkey $(1,3,17,18)$. The families should be informed about the possible harmful effects of circumcision during the phallic phase and that circumcision should not be performed in this phase, unless there is a medical indication. There are a few studies about the long-term psychological effects of male circumcision. Goldman et al. reported that in the USA, circumcised men's feelings generally include anger, sense of 
Table 2. Children's Views on Circumcision $(n=326)$

\begin{tabular}{|c|c|c|}
\hline Variables & Yes, No. (\%) & No, No. (\%) \\
\hline \multicolumn{3}{|l|}{ Why they had circumcision } \\
\hline Because of religious belief & $226(69.3)$ & $100(30.7)$ \\
\hline Cultural reasons & $95(29.1)$ & $231(70.9)$ \\
\hline Familial reasons & $80(24.5)$ & $246(75.5)$ \\
\hline To become a man & $182(55.8)$ & $144(44.2)$ \\
\hline To be healthy & $113(34.7)$ & $213(65.3)$ \\
\hline To be clean & $86(26.4)$ & $240(73.6)$ \\
\hline To look like their father & $52(16.0)$ & $274(84.0)$ \\
\hline To look like a big brother & $41(12.6)$ & $285(87.4)$ \\
\hline To look like other boys & $52(16.0)$ & $274(84.0)$ \\
\hline Do you think that a ceremony is needed for a circumcision? & $169(51.8)$ & $157(48.2)$ \\
\hline Was there a ceremony at your circumcision? & $223(68.4)$ & $103(31.6)$ \\
\hline
\end{tabular}

Table 3. The Association Between Some Variables Related to Circumcision and the Child's Level of Fear, Pain and Grief ${ }^{\mathrm{a}}$

\begin{tabular}{|c|c|c|c|c|c|c|c|c|c|c|c|c|c|c|c|c|c|c|c|}
\hline & & \multicolumn{6}{|c|}{ Level of Fear } & \multicolumn{6}{|c|}{ Level of Pain } & \multicolumn{6}{|c|}{ Level of Grief } \\
\hline & & None & Little & Somewhat & Much & $\begin{array}{l}\text { Too } \\
\text { Much }\end{array}$ & $\mathrm{x}^{2}, \mathrm{P}$ & None & Little & Somewhat & Much & $\begin{array}{l}\text { Too } \\
\text { Much }\end{array}$ & $x^{2}, p$ & None & Little & Somewhat & Much & $\begin{array}{l}\text { Too } \\
\text { Much }\end{array}$ & $\mathrm{x}^{2}, \mathrm{P}$ \\
\hline The place & & & & & & & $\begin{array}{l}30.376, \\
0.000\end{array}$ & & & & & & $\begin{array}{c}38.226 \\
0.000\end{array}$ & & & & & & $\begin{array}{l}19.137 \\
0.014\end{array}$ \\
\hline & At home & $\begin{array}{l}29 \\
(8.9)\end{array}$ & $\begin{array}{c}41 \\
(12.6)\end{array}$ & $28(8.6)$ & $\begin{array}{l}26 \\
(8.0)\end{array}$ & $\begin{array}{c}13 \\
(4.0)\end{array}$ & & $\begin{array}{c}46 \\
(14.1)\end{array}$ & $\begin{array}{c}27 \\
(8.3)\end{array}$ & $26(8.0)$ & $\begin{array}{c}21 \\
(6.4)\end{array}$ & $\begin{array}{c}17 \\
(5.2)\end{array}$ & & $\begin{array}{l}68 \\
(20.9)\end{array}$ & $\begin{array}{c}27 \\
(8.3)\end{array}$ & $19(5.8)$ & $\begin{array}{c}11 \\
(3.4)\end{array}$ & $\begin{array}{c}12 \\
(3.7)\end{array}$ & \\
\hline & In hospital & $\begin{array}{l}74 \\
(22.7)\end{array}$ & $\begin{array}{l}39 \\
(12.0)\end{array}$ & $19(5.8)$ & $\begin{array}{c}13 \\
(4.0)\end{array}$ & $\begin{array}{c}9 \\
(2.8)\end{array}$ & & $\begin{array}{l}95 \\
(29.1)\end{array}$ & $\begin{array}{l}25 \\
(7.7)\end{array}$ & $11(3.4)$ & $\begin{array}{c}14 \\
(4.3)\end{array}$ & $\begin{array}{c}9 \\
(2.8)\end{array}$ & & $\begin{array}{l}93 \\
(28.5)\end{array}$ & $\begin{array}{c}21 \\
(6.4)\end{array}$ & $18(5.5)$ & $\begin{array}{c}12 \\
(3.7)\end{array}$ & $\begin{array}{l}10 \\
(3.1)\end{array}$ & \\
\hline & $\begin{array}{l}\text { Mass cir- } \\
\text { cumcision }\end{array}$ & $\begin{array}{c}12 \\
(3.7)\end{array}$ & $\begin{array}{c}6 \\
(1.8)\end{array}$ & $5(1.5)$ & $\begin{array}{c}6 \\
(1.8)\end{array}$ & $\begin{array}{c}6 \\
(1.8)\end{array}$ & & $\begin{array}{c}7 \\
(2.1)\end{array}$ & $\begin{array}{c}9 \\
(2.8)\end{array}$ & $5(1.5)$ & $\begin{array}{c}7 \\
(2.1)\end{array}$ & $\begin{array}{c}7 \\
(2.1)\end{array}$ & & $\begin{array}{c}8 \\
(2.5)\end{array}$ & $\begin{array}{c}7 \\
(2.1)\end{array}$ & $8(2.5)$ & $\begin{array}{c}6 \\
(1.8)\end{array}$ & $\begin{array}{c}6 \\
(1.8)\end{array}$ & \\
\hline The perso & & & & & & & $\begin{array}{l}27.247, \\
0.000\end{array}$ & & & & & & $\begin{array}{c}26.693, \\
0.000\end{array}$ & & & & & & $\begin{array}{r}17.629 \\
0.001\end{array}$ \\
\hline & Surgeon & $\begin{array}{c}77 \\
(23.6)\end{array}$ & $\begin{array}{l}39 \\
(12.0)\end{array}$ & $17(5.2)$ & $\begin{array}{c}16 \\
(4.9)\end{array}$ & $\begin{array}{c}9 \\
(2.8)\end{array}$ & & $\begin{array}{l}94 \\
(28.8)\end{array}$ & $\begin{array}{l}26 \\
(8.0)\end{array}$ & $14(4.3)$ & $\begin{array}{c}12 \\
(3.7)\end{array}$ & $\begin{array}{c}12 \\
(3.7)\end{array}$ & & $\begin{array}{l}100 \\
(30.7)\end{array}$ & $\begin{array}{l}20 \\
(6.1)\end{array}$ & $17(5.2)$ & $\begin{array}{c}13 \\
(4.0)\end{array}$ & $\begin{array}{c}8 \\
(2.5)\end{array}$ & \\
\hline & $\begin{array}{l}\text { Circum- } \\
\text { ciser }\end{array}$ & $\begin{array}{l}38 \\
(11.7)\end{array}$ & $\begin{array}{l}47 \\
(14.4)\end{array}$ & $35(10.7)$ & $\begin{array}{l}29 \\
(8.9)\end{array}$ & $\begin{array}{c}19 \\
(5.8)\end{array}$ & & $\begin{array}{l}54 \\
(16.6)\end{array}$ & $\begin{array}{c}35 \\
(10.7)\end{array}$ & $28(8.6)$ & $\begin{array}{c}30 \\
(9.2)\end{array}$ & $\begin{array}{c}21 \\
(6.4)\end{array}$ & & $\begin{array}{l}69 \\
(21.2)\end{array}$ & $\begin{array}{l}35 \\
(10.7)\end{array}$ & $28(8.6)$ & $\begin{array}{c}16 \\
(4.9)\end{array}$ & $\begin{array}{l}20 \\
(6.1)\end{array}$ & \\
\hline Anesthes & & & & & & & $\begin{array}{l}16.176 \\
0.040\end{array}$ & & & & & & $\begin{array}{c}15.682 \\
0.047\end{array}$ & & & & & & $\begin{array}{r}26.070, \\
0.001\end{array}$ \\
\hline & $\begin{array}{l}\text { General } \\
\text { anesthesia }\end{array}$ & $\begin{array}{c}49 \\
(15.0)\end{array}$ & $\begin{array}{l}25 \\
(7.7)\end{array}$ & $11(3.4)$ & $\begin{array}{c}15 \\
(4.6)\end{array}$ & $\begin{array}{c}8 \\
(2.5)\end{array}$ & & $\begin{array}{c}64 \\
(19.6)\end{array}$ & $\begin{array}{c}15 \\
(4.6)\end{array}$ & $8(2.5)$ & $\begin{array}{c}14 \\
(4.3)\end{array}$ & $\begin{array}{c}7 \\
(2.1)\end{array}$ & & $\begin{array}{l}67 \\
(20.6)\end{array}$ & $\begin{array}{c}15 \\
(4.6)\end{array}$ & $10(3.1)$ & $\begin{array}{c}9 \\
(2.8)\end{array}$ & $\begin{array}{c}7 \\
(2.1)\end{array}$ & \\
\hline & $\begin{array}{l}\text { Local } \\
\text { anesthesia }\end{array}$ & $\begin{array}{l}56 \\
(17.2)\end{array}$ & $\begin{array}{l}51 \\
(15.6)\end{array}$ & $35(10.7)$ & $\begin{array}{c}21 \\
(6.4)\end{array}$ & $\begin{array}{c}13 \\
(4.0)\end{array}$ & & $\begin{array}{l}68 \\
(20.9)\end{array}$ & $\begin{array}{l}39 \\
(12.0)\end{array}$ & $27(8.3)$ & $\begin{array}{c}22 \\
(6.7)\end{array}$ & $\begin{array}{l}20 \\
(6.1)\end{array}$ & & $\begin{array}{l}88 \\
(27.0)\end{array}$ & $\begin{array}{l}35 \\
(10.7)\end{array}$ & $29(8.9)$ & $\begin{array}{c}13 \\
(4.0)\end{array}$ & $\begin{array}{c}11 \\
(3.4)\end{array}$ & \\
\hline & $\begin{array}{l}\text { No } \\
\text { anesthesia }\end{array}$ & $\begin{array}{c}10 \\
(3.1)\end{array}$ & $\begin{array}{c}10 \\
(3.1)\end{array}$ & $6(1.8)$ & $\begin{array}{c}9 \\
(2.8)\end{array}$ & $\begin{array}{c}7 \\
(2.1)\end{array}$ & & $\begin{array}{c}16 \\
(4.9)\end{array}$ & $\begin{array}{c}7 \\
(2.1)\end{array}$ & $7(2.1)$ & $\begin{array}{c}6 \\
(1.8)\end{array}$ & $\begin{array}{c}6 \\
(1.8)\end{array}$ & & $\begin{array}{c}14 \\
(4.3)\end{array}$ & $\begin{array}{c}5 \\
(1.5)\end{array}$ & $6(1.8)$ & $\begin{array}{c}7 \\
(2.1)\end{array}$ & $\begin{array}{c}10 \\
(3.1)\end{array}$ & \\
\hline Age & & & & & & & $\begin{array}{l}17.246 \\
0.028\end{array}$ & & & & & & $\begin{array}{c}10.718 \\
0.218\end{array}$ & & & & & & $\begin{array}{l}8.865, \\
0.354\end{array}$ \\
\hline & $0-2$ years & $\begin{array}{l}24 \\
(7.4)\end{array}$ & $\begin{array}{c}8 \\
(2.5)\end{array}$ & $6(1.8)$ & $\begin{array}{c}8 \\
(2.5)\end{array}$ & $\begin{array}{c}7 \\
(2.1)\end{array}$ & & $\begin{array}{c}29 \\
(8.9)\end{array}$ & $\begin{array}{c}7 \\
(2.1)\end{array}$ & $5(1.5)$ & $\begin{array}{c}7 \\
(2.1)\end{array}$ & $\begin{array}{c}5 \\
(1.5)\end{array}$ & & $\begin{array}{c}24 \\
(7.4)\end{array}$ & $\begin{array}{c}7 \\
(2.1)\end{array}$ & $8(2.5)$ & $\begin{array}{c}8 \\
(2.5)\end{array}$ & $\begin{array}{c}6 \\
(1.8)\end{array}$ & \\
\hline & $3-6$ years & $\begin{array}{c}38 \\
(11.7)\end{array}$ & $\begin{array}{l}48 \\
(14.7)\end{array}$ & $24(7.4)$ & $\begin{array}{l}25 \\
(7.7)\end{array}$ & $\begin{array}{c}11 \\
(3.4)\end{array}$ & & $\begin{array}{l}54 \\
(16.6)\end{array}$ & $\begin{array}{c}31 \\
(9.5)\end{array}$ & $25(7.7)$ & $\begin{array}{c}18 \\
(5.5)\end{array}$ & $\begin{array}{c}18 \\
(5.5)\end{array}$ & & $\begin{array}{l}74 \\
(22.7)\end{array}$ & $\begin{array}{l}30 \\
(9.2)\end{array}$ & $16(4 . .9)$ & $\begin{array}{c}12 \\
(3.7)\end{array}$ & $\begin{array}{c}14 \\
(4.3)\end{array}$ & \\
\hline
\end{tabular}


loss, shame, sense of having been victimized and violated, fear, distrust, grief and jealousy of intact men (19). Similarly, Hammond stated that circumcised men have emotional distress, including feelings of mutilation, low selfesteem, genital dysmorphia, rage, depression, violation or parental betrayal (20).

When the boys in our study were asked about the most suitable age for circumcision, a large number of them stated that it was during infancy, and the reasons most stated for their answers were that this was the most suitable time, the pain would be less, the procedure would be easier and the procedure would be without fear. In their study, Ustuner et al. stated that mothers most often chose age of three to six years as the most suitable age to be circumcised and stated that they chose this age because they thought that the child would not be afraid (16). In the same study, only $4.1 \%$ of the families stated that infancy would be the best age for circumcision and that healing quickly was their reason for choosing this period (16).

Circumcision is something that is done for religious beliefs, traditions or health. At the same time, it is considered to be the beginning of a boy's sexual life and the ability to reproduce. When children, who participated in this study, were asked why they were circumcised, 69.3\% stated that it was for religious reasons, while $55.8 \%$ stated that circumcision was necessary to be a man. In their study, Yllmaz et al. stated that mothers reported religious reasons as the primary reason for circumcision due to being part of a Muslim society (15). In Ustuner et al.'s study, about half of the families thought circumcision was necessary because of its positive effects on health, while the other half thought it was necessary for religious reasons (16). In Sahin et al.'s study, most of the mothers stated that their reasons for circumcision were religious and traditional, while very few of them stated that the medical benefits were their primary reasons (3). In the same study, it was found that the mothers whose levels of education were low tended to want circumcision for traditional and religious reasons (3). In Turkey, circumcision is believed to be the beginning of the process of becoming a man and a member of society, and not being circumcised is unacceptable (3).

An important aspect of circumcision in Turkey is the moral values of the society. Circumcision is the first sign of a boy's transition into manhood in Turkish culture (3). It is usually carried out with ceremonies accompanied frequently by music and entertainment that are important social events for families (21). Therefore, it is a ritual used to be celebrated with music and dance or prayers together with guests and relatives, according to the preferences of the family. In this ritual, the child, who most commonly wears a special bright costume with a pelerine and wand looks like a king. Also, his courage is rewarded by giving him various presents $(3,22)$. It is important for the child to experience these moments and remember them in the future $(23,24)$. This thought is considered as a reason of having a late circumcision in Turkey. In our study, half of the children stated that a ceremony was necessary, and $68.4 \%$ stated that they had a ceremony for their circumcision. Three quarters of the children stated that they underwent their circumcision willingly. These results suggested that circumcision has quite positive connotations from children's perspectives.

Informing the child with respect to his age in advance to the surgical procedure is essential. In our study it was found that children were not informed regarding this procedure. The reason for this was that children might not have been informed in circumcisions, which took place in other places than hospitals and performed by circumcisers, not doctors. Nowadays, operations are carried out by surgeons and circumciser (25). Traditional circumcisers are still preferred by parents $(3,22)$. In Corduk et al.'s study, it was found out that $42 \%$ of boys were operated on by a circumciser (23). Our results indicate that the traditional approach is still common in Turkey.

Our study found that $54.6 \%$ of the children had various levels of pain during the procedure. Additionally, in our study the children were mostly anesthetized locally. We also found that a circumcision performed at a hospital, under general anesthesia and by a surgeon effectively reduces pain. When the levels of pain were analyzed in terms of age, it was found that the levels of pain experienced by the children between three and six years of age were higher than those in other groups.

In our study, a significant association was found between the place where circumcision was performed, the person who performed the circumcision, the type of anesthesia used and the pain, fear and grief of the child. The children, who were circumcised at home, those who were circumcised by a circumciser, those who were circumcised without being anesthetized and those who were circumcised in the phallic phase experienced more fear during circumcision. Sahin et al. found that ten boys, who were younger than three years remembered being afraid while they were being circumcised. The majority of the children, who were circumcised during phallic phase experienced negative feelings during circumcision, that is, they had anxiety (3). In our study, 38.4\% of children had more than moderate fear. When Verit et al. asked male health care professionals what children felt during their circumcision, $33 \%$ stated that they experienced fear (22).

Children, who are going to have a circumcision, develop a fear weeks or months before the procedure. In addition to not knowing what will happen, children may not want to expose their genital organ to others, they may 
fear that they will experience pain and changes, such as sleeplessness, unrest and rebellious or aggressive behavior. Knowledge that other children are being circumcised by force and without an explanation of what's going to happen, without being prepared and anesthetized will increase fear and psychic trauma. In Corduk et al.'s study, $38 \%$ of boys stated that they were frightened during circumcision (23). In their study, Verit et al. stated that of males between 25 and 45 years of age, $81 \%$ stated that they were circumcised by traditional circumcisers rather than surgeons and $90 \%$ were found to have been circumcised at home (22). Previously, circumcision was performed by traditional circumcisers. However, when the results of the study were analyzed, a transition was seen in the provider of circumcision, from circumcisers to surgeons. In their study, Sivasl et al. found that $72 \%$ of the families stated that circumcision should be performed at a hospital (26). These results show that Turkish people are becoming more conscious. However, the rates of preferring surgeons for circumcision are still not at desired levels. Circumcision should always be performed at hospitals by surgeons, who are familiar with the procedure (11).

The sample of this study consisted of children living in a city in Turkey. The findings cannot be generalized for all Turkish children.

\subsection{Conclusion}

It was found that, almost half of the children, who were not sufficiently informed before circumcision were circumcised at an unsuitable age and that they experienced too much pain and fear during the procedure. The results of this study indicated the necessity of public education on circumcision. Based on these results, recommendations can be made to educate families about circumcisions. Before the circumcision, the procedure should be explained clearly to the child, and he should be prepared psychologically. Families should be educated that circumcisions are performed in hospitals by surgeons, in a suitable age range and with optimal pain management.

\section{References}

1. Weiss H, Larke N, Halperin D, Schenker I. Neonatal and child male circumcision: a global review. [cited March 12]. Available from: http://www.who.int/hiv/pub/malecircumcision/neonatal_child_ MC_UNAIDS.pdf?ua=1.

2. WHO . Male circumcision: global trends and determinants of prevalence, safety and acceptability 2007. [cited March 12]. Available from: http://www.who.int/reproductivehealth/publications/rtis/ 9789241596169/en/pdf.

3. Sahin F, Beyazova U, Akturk A. Attitudes and practices regarding circumcision in Turkey. Child Care Health Dev. 2003;29(4):275-80. doi: 10.1046/j.1365-2214.2003.00342.x. [PubMed: 12823332].
4. CIRP L. The bioethics of the circumcision of male children 2013. [cited December 21]. Available from: http://www.cirp.org/library/ethics/ index_tk.html.

5. Earp BD. Female genital mutilation (FGM) and male circumcision: Should there be a separate ethical discourse?.Practical Ethics. 2014;5:113.

6. Altay B, Kocak D, Nazli O, Simsir A . Sunnet uyguladigi olgularda fimozis siligidnan menderes uiversitesi tıp fakultesi dergisi [in Turkish]. $2000 ; 1(3): 21-3$.

7. Kelez AEU. An analysis of the information level and behaviors of families who came to pediatric surgery clinic. Izmir: Ege University; 2002.

8. Ozturk O. Turk toplumunda sunnet ve igdislik korkusu sorunu: Ruh saglıgı ve bozuklukları (turkish). 8. Ankara: Feryal Matbaasi; 2001.

9. Ocakcı A , Yigen E . Cocuk saglıgı ve hastalıklarında atravmatik hemșirelik bakımı [in Turkish]. Ege Üniversitesi Hemșirelik Yüksekokulu Dergisi. 2004;20(1):117-25.

10. Tekgul S. Circumcision. Cocuk saglıgı ve hastalıkları dergisi (turkish) 2000. [cited April 10]. Available from: http://www.cshd.org.tr/csh/ pdf/pdf_CSH_39.pdf.

11. Official Gazzette . Saglık Bakanlıgı Ve Baglı Kuruluşlarının Teskilat Ve Gorevleri Hakkında Kanun Hukmunde Kararname Ile Bazı Kanunlarda Degisiklik Yapılmasına Dair Kanun (Turkish) 2014. [cited April 2]. Available from: http://www.resmigazete.gov.tr/eskiler/2014/01/ 20140118-1.htm.

12. Ahmed A. Childhood circumcision: a planned approach. Trop Doct. 2007;37(4):239-41. doi: 10.1258/004947507782332865. [PubMed: 17988494].

13. Adler R, Ottaway S, Gould S. Circumcision: we have heard from the experts; now let's hear from the parents. Pediatrics. 2001;107(2):20. doi: 10.1542/peds.107.2.e20.

14. Cataklı T, Yazarlı E, Yener F, Bïlge YD. Knowledge levels about circumcision of mothers admitted to a hospital. Erciyes Med J. 2012;34(3):11620. doi: 10.5152/etd.2012.35.

15. Yılmaz Y, Ozsoy SA, Ardahan M. Annelerin sunnet hakkındaki davranıs ve bilgi düzeylerinin incelenmesi. Ege Tip Dergisi. 2008;47(2).

16. Top FU, Timur YE, Uykan L, Pekdemir A. The Knowledge, behavior and attitude about of circumcision in families in Giresun [in Turkish]. Cocuk Dergisi. 2008;8(3):166-71.

17. Cankorkmaz L, Çetinkaya S, Köylüoğlu G. General Practitioner Knowledge Levels About Circumcision [in Turkish]. Balkan Med J. 2011;28:264-8. doi:10.5174/tutfd.2010.03758.4.

18. Aydur E, Gungor S, Ceyhan ST, Taiimaz L, Baser I. Effects of childhood circumcision age on adult male sexual functions. Int JImpot Res. 2007;19(4):424-31. doi:10.1038/sj.ijir.3901545. [PubMed: 17314981].

19. Goldman R. The psychological impact of circumcision. BJU Int. 1999;83 Suppl 1:93-102. doi: 10.1046/j.1464-410x.1999.0830s1093.x. [PubMed: 10349420].

20. Hammond T. A preliminary poll of men circumcised in infancy or childhood. BJU Int. 1999;83 Suppl 1:85-92. doi: 10.1046/j.1464410x.1999.0830s1085.x. [PubMed: 10349419].

21. Yavuz M, Demir T, Dogangun B. [The effect of circumcision on the mental health of children: a review].Turk Psikiyatri Derg. 2012;23(1):6370. [PubMed: 22374633].

22. Verit A, Aksoy S, Yeni E, Unal D, Ciftci H. A limited study on the perception and change in attitude about circumcision among health care professionals and their male family members. Urol Int. 2002;69(4):302-5. doi: 10.1159/000066130. [PubMed: 12444288].

23. Corduk N, Unlu G, Sarioglu-Buke A, Buber A, Savran B, Zencir M. Knowledge, attitude and behaviour of boys and parents about circumcision. Acta Paediatr. 2013;102(4):169-73. doi: 10.1111/apa.12152. [PubMed: 23298264].

24. Toksoy G, Tasitman A. . "Ceremonial circumcision" as one of the mechanisms which enables the regeneration and intergenerational transmission of manhood culture in Turkey.A Journal of Identity and Culture. 2015;33:156-88. 
25. Turkish Cultural Foundation (TCF). . Republic of Turkey Ministry of Culture and Tourism [cited January 27]. Available from: http://www.turkishculture.org/lifestyles/ceremonies/circumcision/ tradition-of-circumcision-541.htm?type $=1$.
26. Sivaslı E, Bozkurt AI, Ceylan H, Coşkun Y. Gaziantep bolgesindeki anne ve babaların sünnet ile ilgili bilgi, tutum ve davranışları. Cocuk sagligi ve hastallklarn dergisi. 2003;46(2):114-8. doi: 10.1046/j.13652214.2003.00342.x. 